\title{
The Impact of Japanese Population in Kupang City Year 1942-1945 for Women
}

\author{
Melki Oktofianus Lalay \\ History of Education, Universiti Persatuan Guru 1945 Ntt, Indonesia
}

\begin{abstract}
Background This research: is to reconstruct (1) the Impact of the Japanese Occupation in Kupang City for women in the social field of 1942-1945, (2) The Role of Women in the social field in Kupang City during the Japanese Occupation of 1942-1945. This research is located in all areas of Kupang. Data Analysis Techniques in this writing were collected through interviews, observations, literature studies, and document studies. The analysis technique used is historical analysis. The results showed (1) the impact of the Japanese occupation in Kupang in 1942-1945 for women in the social field. (2) Impact of Japanese occupation on Kupang City in 19421945 for women in the social field.

This research method: uses qualitative descriptive research type. Determination of Informants is done by purposive sampling. The person who was made the informant was a person who experienced the events directly during the Japanese occupation in Kupang City in 1942-1945 or people who were considered to have known the events during the Japanese occupation in Kupang City in 1942-1945. Data collection techniques are carried out by interview, observation, literature study, and document study. Data analysis techniques using historical analysis techniques with heuristic steps, verification, interpretation, and historiography

Research Results: Show that during the Japanese occupation the daily government was held by Menseibu, which was led by the Japanese navy, the people of Kupang City experienced poverty and hunger, this made Indonesian women especially in Kupang City obliged to work forcefully. The Japanese occupation period in Indonesia in 1942-1945 was a dark period for Indonesian women, especially women in Kupang City when their teenagers were forcibly taken away, their actions were very inhumane, Japan forcibly arrested girls and was taken to brothels. Many young women who experience sexual violence are no exception indigenous women. Indonesian women consider the Japanese occupation a sex predator

Conclusion: During the Japanese occupation in Indonesia (1942-1945) was a dark period for Indonesian women. Their teenage years were snatched away by force, they were made Jugun Ianfu (Sex Slaves) of the Japanese royal army to meet the sexual needs of his soldiers. When the Japanese invaded and waged war on other countries, the Japanese army was mentally exhausted. This condition resulted in the Japanese army brutalizing sexual outlet by mass raping which resulted in an outbreak of venereal disease affecting the Japanese army. This certainly weakened the strength of the Japanese imperial army. This situation gave rise to the idea of recruiting local women, and putting them into brothels and making them comfort women (JugunYanfu) to satisfy the Japanese army. During the Japanese occupation the daily administration was held by General Murakami.
\end{abstract}

Keywords: Japanese Occupation, Impact, Women.

DOI: $10.7176 / \mathrm{HRL} / 52-02$

Publication date: December $31^{\text {st }} 2020$

\section{I.INTRODUCTION}

History is an event or event that has happened in the past in the history of human life. Events that have happened in the past certainly leave traces of history so that events can be known by subsequent generations. The history of human life in the environment where it is located is inseparable from various events that have an impact on human life. One historical event that describes the development of human life. History cannot be separated from social facts that arise in human life because, the emergence of historical events that can be influenced by social factors that occur in people's lives. Not all events that occur in public life are said to be historical events because an event is said to be a historical event that meets at least three criteria, namely: (1) classified as a significant event (2) classified as a unique event (3) classified as an eternal event.

Based on the three criteria above, it can be ascertained that the history of women during the Japanese occupation in the city of Kupang is also an event that is said to be a historical event classified in women's history that needs to be explored more deeply because it has a very negative impact on women and also affects the lives women in Kupang City.Not many people know about the history of Kupang City. Not everyone also knows what happened in the city of Kupang during World War II. Kupang City during World War II was occupied by Japan in 1942-1945 or more or less three years. The city of Kupang was also destroyed by the Japanese army when fighting against the Australian army in 1942. At that time the war broke out in the whole area of the city of Kupang which caused an increasingly tense atmosphere and a very bad impact on the people of Kupang, especially bad impact on women during World War II. This event was not yet known with certainty the causes until Japan occupied Kupang City and what impact it had on women. The reality of the problem of women that 
occurred in the city of Kupang during the Japanese occupation in 1942-1945 should be examined to find out what the impact was.

The atrocities committed by Japan for three and a half years in Indonesia were no less than the atrocities committed by the Dutch during the colonial period which in some regions in Indonesia lasted more than 300 years. Misery suffered by the people of Indonesia due to the oppression of the Japanese occupation army. In addition to forced labor (Romusha) which is very inhumane, as well as a very degrading treatment of women, that is forcing Indonesian girls to be comfort women (Jugun Yanfu) to satisfy the Japanese army.

The Japanese occupation of Kupang in 1942-1945 had a significant impact on women who needed to be explored more deeply and needed to find out what kind of impact the women had in Kupang City and what their role was during the Japanese occupation.

\section{Material And Methods}

Study Design: Using historical research designs that were analyzed using descriptive quantitative analysis methods from interview results. Study Location: The location of this research is the whole area of Kupang City. The reason is that the area was occupied by Japan in 1942-1945, and there were many informants.

Study Duration: for one year from March 1, 2018 to March 1, 2019

Determination of Informants: Determination of Informants is done by purposive sampling which means determining informants based on the consideration of researchers. The person who was made the informant was a person who experienced the events during the Japanese occupation in Kupang City in 1942-1945 or people who were considered to have known the events during the Japanese occupation. physically and mentally healthy and honest in providing information.

Data Sources: Data sources needed in this study consist of Primary data sources and Secondary data sources: Primary Data Sources Primary data sources are informants who experienced, and witnessed firsthand the Japanese occupation in Kupang City. Or people who were eyewitnesses in the event of Japanese occupation in Kupang City that were believed by researchers to be able to provide clear information and a picture of the period of Japanese occupation or occupation of Kupang in 1942-1945.

Secondary Data Sources Secondary data sources in the form of books, articles, journals that are relevant to the research problem.

Data Collection Techniques: Interview, observation. Collecting data, we must enter that world and we must see for ourselves what is happening. In this research activity the researcher will observe directly the various historical relics which are the former occupation of the Japanese occupation in Kupang City and also interview women who experienced firs hand the events during the Japanese occupation / occupation in the City of Kupang. The observations were recorded with a camera to be documented. The research location is in the city of Kupang. Things that will be observed are Japanese heritage objects such as cannons, monuments / monuments, caves where Japanese soldiers hid, and also interviewed Women who experienced firs hand the Japanese occupation in Kupang City in 1942-1945. Literature study is a way of collecting data through written relics such as archives of opinions related to women's history.

Data Analysis Techniques. The data analysis technique used in this study is the historical analysis techniqu

\section{III.B. RESEARCH RESULTS}

\section{Japanese Occupation in Kupang City in 1942-1945.}

During the Dutch colonial era, the Government was implemented by using a deconcentrated system until Japan landed in Indonesia (Timor Island). Japan landed in Kupang (Timor) on 18 and 19 February 1942 in two places, namely on the South Coast of Timor Island in the Amarasi region, precisely in the Oepaha region. In that area the Japanese army did not get any resistance at all they landed from the sea. Air landing (paratroopers) occurred in the area around Babau and Oesao, in the two regions the Japanese army was very fierce resistance from the Australian army. Victims fell on both sides. Because there were too many Japanese troops, the Australian army was forced to withdraw from the battlefield and continue with guerrilla warfare in the interior of Timor. With the withdrawal of the Australian army from the battlefield in Oesao and Babau, the Japanese army freely entered Kupang City without resistance.

During the Japanese occupation in Indonesia (1942-1945) was a dark period for Indonesian women. Their teenage years were snatched away by force, they were made Jugun Ianfu (Sex Slaves) of the Japanese royal army to meet the sexual needs of his soldiers. When the Japanese invaded and waged war on other countries, the Japanese army was mentally exhausted. This condition resulted in the Japanese army brutalizing sexual outlet by mass raping which resulted in an outbreak of venereal disease affecting the Japanese army. This certainly weakened the strength of the Japanese imperial army. This situation gave rise to the idea of recruiting local women, and putting them into brothels and making them comfort women (JugunYanfu) to satisfy the Japanese army.

The Japanese army was very feared by women at that time, there were no girls who roamed carelessly 
because Japanese soldiers could come at any time to take the girls and wives of the people they liked. Nobody dares to oppose the will of Japan. According to informants Martha pati Ndun Japan was very rude and cruel they did not hesitate to kill if they did not follow their orders. In the military Japanese troops with the rank of star are very rude and cruel soldiers. There is no mercy for those who oppose the rules that have been set if there is a violation, they will immediately be shot dead. While the Army bearing the Anchor is still very good and there is still a soul of love or sense of mother.

Many parents hide their daughters for fear of being taken by Japanese soldiers and taken to brothels. The brothel has guards, the guards are called Opas. Opas means the guardian of a Japanese brothel. Many girls hid in the attic because of fear, some because of fear they fled to the forest and were eaten by snakes to death. Even the Japanese army forced men to bring girls to brothels if they did not obey their wishes then they would be punished by cutting their thighs like chickens. According to informant Albert Zakarias the Japanese army took women aged 15-35 years. Japan does not care for women who are taken because there are women whose status is the wife of the community but are still taken and taken to brothels. In fact, according to informant 03 , the men who wanted to protect their sister from the Japanese army claimed that their sister was his wife, so the Japanese army forced them to engage in marital relations in front of the Japanese army. After doing so the Japanese soldiers tortured the man by beating him to death. The Japanese leader at that time was General Murakami. Japan is very cruel according to informant Kale Pau Riwu, who was once a Japanese aide, said that after the girls were taken to brothels they were given soap to bathe, and were prepared to serve Japanese soldiers. One girl was raped by 7-8 Japanese soldiers. many women die in brothels because of illness, suicide, or tortured to death.

But there are also Japanese soldiers who like to marry village girls. The proof is in Kupang there are still many descendants of Japanese children. This statement was strengthened by informant 05 Nyora Foeh who was of Japanese descent, according to her father, a Japanese person, her father's name was Motosam. He also confirmed that he received benefits from his father. But as time goes by he doesn't get any more benefits. There are still many Indonesian Japanese Jugun and descendants of Japanese children who are still alive and have died that have not been traced to their existence.

The Role of Women in Social Affairs in Kupang City during the Japanese Occupation of 1942-1945:

During the Japanese occupation the daily government was held by General Murakami. The role of women during the Japanese occupation in Kupang City was very large. The situation in Kupang City at that time was not like it is now. During the Japanese occupation the community experienced poverty and hunger, Poverty experienced by the community made Indonesian women especially in Kupang play a role in helping meet the needs of their family life. The role of these women is inseparable from the impact felt by women at that time, with this situation the mothers and the girls struggled to meet their economic needs by concocting marine products and made as one way to meet the needs of life them. By making salt that is processed from the sea and processed salt is exchanged for the Japanese Army.

At that time the people of Kupang were subject to the term Barter or the exchange between the results they managed. So the salt that has been processed by the women is then exchanged with the Japanese Army for corn. The corn owned by the Japanese Army was actually the work of the orchards of the people of Kupang who were forced to work corn gardens for the Japanese Army. Women at that time also acted as fishermen and fishing in the sea. The seafood is then exchanged for rice and tapioca flour. In addition to playing the role of farmers and fishermen for women in Kupang, it also plays an active role in helping the Japanese army to meet the physical needs of Japanese soldiers. Women work for General Murakami. The work carried out included sewing pillows and sleeping mattresses, ironing clothes for the Japanese army, and there were also women who worked as servants for the Japanese army such as washing clothes and cooking food for Japanese soldiers. There were very many roles of women during World War II. The women were kindly requested by General Murakami to work as a servant to the Japanese army. The girls who worked for the Japanese army were rewarded by General Murakami, namely money. The currency used during the Japanese occupation of Kupang in 1942-1945 was the Japanese currency, the yen.

Not only that, the role of women in the social field, one of which is to help the people of Kupang, such as helping pregnant women because at that time the availability of health services, such as the absence of hospitals, doctors, nurses and midwives, to give birth. These women have a great passion for helping others, and they show a high sense of solidarity between people.

Impact of Japanese Occupation in Kupang City in 1942-1945 for Women in the Social Field.

Impact of the Japanese Occupation in Kupang City in 1942-1945 for the people of Kupang City, the impact was classified as positive and negative impacts.

Negative impact. Physical violence for women:The impact that occurred during the Japanese occupation for the community, one of which was that many women in Kupang were used as an outlet for Japanese desires. They were recruited in a violent manner, terrorizing with acts of violence, kidnapping and even raping. Atrocities committed by Japan for three and a half years in the city of Kupang caused various misery suffered by the people of Kupang due to the suppression of the occupation of the Japanese army. 
Women at that time were tortured by the arbitrary actions of Japanese soldiers against women. To satisfy the desires of the Japanese army, the Japanese made long houses with lots of rooms, they were called brothels. The purpose of the brothel was built to be a place to accommodate the girls they made as comfort women (Jugun Yanfu). This brothel was built by the people of Kupang, the Japanese army is very evil who does not want to obey their desires will be killed so that the people are afraid and obey their desires. you could say that women no longer had any self-respect, they were forced to serve the sexual needs of Japanese soldiers.

psychological violence: The arrival of Japan in the city of Kupang caused a very deep fear for the people of Kupang. The Kupang community was depressed and shocked, and the Japanese forces were very cruel and inhumane. The psychological impact of the Japanese Occupation in Kupang City was that the survivors were still living up to the present and it was difficult to forget this bad experience, they were still afraid, prolonged trauma, depression, shame and sadness when asked to share their experiences in the past.

Victims who died: The Japanese occupation period in Kupang City in 1942-1945 resulted in many casualties, fatalities not only from the Japanese troops who were indeed at the time of the war against the Australian Sparrow Force but also many people died in Kupang residents, especially City women Kupang. Many women in Kupang City became vain victims of the Japanese Occupation, many women were forced to serve the sexual needs of the Japanese Army, but there were women who chose to hide in the forest and die from being eaten by snakes rather than being comfort women or Jugun Yanfu. These women fell victim to the cruelty of Japanese soldiers.

\section{IV.Conclusion}

During the Japanese occupation in Indonesia (1942-1945) was a dark period for Indonesian women. Their teenage years were snatched away by force, they were made Jugun Ianfu (Sex Slaves) of the Japanese royal army to meet the sexual needs of his soldiers. When the Japanese invaded and waged war on other countries, the Japanese army was mentally exhausted. This condition resulted in the Japanese army brutalizing sexual outlet by mass raping which resulted in an outbreak of venereal disease affecting the Japanese army. This certainly weakened the strength of the Japanese imperial army. This situation gave rise to the idea of recruiting local women, and putting them into brothels and making them comfort women (JugunYanfu) to satisfy the Japanese army. During the Japanese occupation the daily government was held by General Murakami. The role of women during the Japanese occupation in Kupang City was very large. The situation in Kupang City at that time was not like it is now. During the Japanese occupation the community experienced poverty and hunger, Poverty experienced by the community made Indonesian women especially in Kupang play a role in helping meet the needs of their family life. The role of these women is inseparable from the impact felt by women at that time, with this situation the mothers and the girls struggled to meet their economic needs by concocting marine products and made as one way to meet the needs of life them. By making salt that is processed from the sea and processed salt is exchanged for the Japanese Army. . In addition to playing the role of farmers and fishermen for women in Kupang, it also plays an active role in helping the Japanese army to meet the physical needs of Japanese soldiers. Women work for General Murakami.

\section{References}

1. Abdulgani, 1963. Pengguna Ilmu Sejarah. Djakarta: Prapantja.

2. Abdullah, Taufik dan Abdurrahman Surjomiharjo (ed), Ilmu Sejarah dan Historiograf Arah dan Perspektif. Jakarta: Gramedia.

3. Ali Mohammad, 2005. Pengantar ilmu sejarah Indonesia. Yogyakarta: LkiS

4. Arikanto, 1996. Metode Penelitian dan Kuantitatif. Rineka Cipta, Jakarta

5. Arikanto, Suharsimi. 2003. Manejemen Penelitian. Jakarta: Rineka Cipta.

6. Baum, Willa K, 1975. Oral history for the local historical society (second edition) tanesse: American Association for State and local history Nashville

7. Chew, Daniel, 2000, “ Oral history methodology; the life history approach". Singapore: instate of Southeast Asia Studies

8. Gottschalk, Louis, 1986. Mengerti Sejarah Jakarta: Universitas Indonesia

9. Gazhalba, S. 1996. Pengantar Sejarah Sebagai Ilmu. Jakarta: Bharata Aksara.

10. Harian umum (Pos Kupang. 2012, Edisi Sabtu 18 Februari \& Minggu 23 September)

11. Margono. 2005. Metode Penelitian pendidikan. Jakarta: Rineke Cipta

12. Moeliono, Anton M, 1988, Departemen Pendidikan dan Kebudayaan, Jakarta, Balai Pustaka

13. Mulia, T.S.G; tt, Ensiklopedia Indonesia, Bandung: N-Z, N, V, Penerbitan W. Van Ho eve. S- Gravenhage

14. Nasution, S. 2003. Metode Penelitian Neturalistik Kualitatif. Bandung: Tarsito.

15. Satori Djam'an, 2010. Metode Penelitian Kualitatif. Bandung: Alfabeta

16. Widja, I. G. 1988, Pengantar Ilmu Sejarah, Sejarah Dalam Perspektif Pendidikan. Semarang: Setya Wacana 